\title{
ELECTRODE AND FILLER MATERIALS FOR SURFACING AND WELDING OF CAST TIN BRONZES (Review)
}

\author{
T.B. MAJDANCHUK
}

E.O. Paton Electric Welding Institute, NASU

11 Bozhenko Str., 03680, Kiev, Ukraine. E-mail: office@paton.kiev.ua

\begin{abstract}
Tin bronzes find wide application in machine-building, metallurgy and other branches of industry. They are used for manufacture of parts operating under conditions of increased wear resistance by casting method. Welding and surfacing processes are used for production, as well as elimination of pouring spoilage and repair of parts from tin bronzes. This review gives an analysis of existing developments in area of current technological processes of welding and surfacing of tin bronzes, as well as new electrode and filler materials for these purposes. The main difficulties were considered appearing during application of welding processes, namely high porosity susceptibility (copper alloys are more susceptible), formation of solidification cracks in welds and HAZ, tin liquation, that results in structure inhomogeneity, as well as high susceptibility to hot crack formation in deposited bronze metal or steel during bronze on steel surfacing. Described are the methods of welding and surfacing of cast tin bronzes, among which argon-arc welding, submerged-arc welding and manual coated-electrode arc welding are the most widespread. It is shown that wires and strips from wrought alloys used as electrode and filler materials do not provide the necessary chemical composition of the deposited metal. Development of special flux-cored wires and coated electrodes, providing optimized metal alloying and receiving of necessary properties, is preferable. For example, welding consumables, chemical composition and properties of which would correspond to the base metal, are necessary for welding and surfacing of cast tin bronzes (BrO10F1, BrO5Ts5S5). A conclusion was made based on performed analysis about necessity of development of new consumables (coated electrodes, flux-cored wires) for welding and surfacing of bronzes of critical designation. 40 Ref., 4 Tables. 1 Figure.
\end{abstract}

Ke $\boldsymbol{y} \boldsymbol{w} \boldsymbol{o} \boldsymbol{r} \boldsymbol{d} \boldsymbol{s}:$ tin bronzes, electrode materials, methods of welding and surfacing, metallurgical peculiarities

Today copper-based alloys such as tin bronzes find wide application in assemblies and friction pairs of machines and mechanisms operating under conditions of increased wear resistance at different operation modes. This to significant extent is promoted by favorable combination of their physical and technological properties.

Melting of parts from tin bronzes using new casting methods [1] increases every year. However, at that complete elimination of spoilage is impossible (1-10\% depending on production standards and technical level of casthouses, and $50-70 \%$ at manufacture of complex castings) [2]. The problem of spering application of these metals is relevant since tin bronzes refer to scarce and expensive alloys, the demand and price on which constantly grow [3, 4].

Partially, elimination of cast spoilage is solved through application of different welding processes (surfacing, welding and welding-up). Also these processes are used for:
- repair of worn bronze parts, increasing in such a way their service life;

- manufacture of bimetal parts instead of allcast ones for economy of expensive metal, as well as reduction of total weight of part;

- production of cast-welded parts of complex configuration instead of cast ones.

The aim of present review is the analysis of properties of existing grades of tin bronzes, determination of main difficulties, appearing in welding and surfacing of given alloys, as well as generalizing of data on welding processes and filler materials used for welding and surfacing of tin bronzes.

Commercial grades of cast tin bronzes. Tin bronzes containing together with tin such alloying elements as zinc, lead, phosphorous and nickel [5-7] (Table 1) are used in industry as a rule.

Zinc is added for increase of corrosion resistance of bronze in the salt water as well as for uniform distribution of high-density lead in the alloy. Besides, zinc is cheaper than tin and copper.

Lead is virtually insoluble in tin bronze in solid state. It rises antifriction properties, density of castings as well as improves machinability, but, at that, reduces their mechanical properties. 
INDUSTRIAL

Table 1. Grades of cast tin bronzes [5]

\begin{tabular}{|c|c|c|c|c|}
\hline \multirow{2}{*}{ Alloy } & CIS & USA & Germany & Japan \\
\hline & GOST 613-79 & $\begin{array}{c}\text { ASTM B30, B427, B0505, } \\
\text { B584 }\end{array}$ & DIN 17656 & JIS H5111, H5113, H5115 \\
\hline Copper-tin & - & C91000 & SnBz14 (2.1057) & \\
\hline Tin-nickel & $\begin{array}{l}- \\
- \\
-\end{array}$ & $\begin{array}{l}\text { C96000 } \\
\text { C91700 } \\
\text { C96800 } \\
\end{array}$ & $\begin{array}{l}- \\
- \\
-\end{array}$ & $\begin{array}{l}- \\
- \\
-\end{array}$ \\
\hline Tin-phosphorous & $\begin{array}{c}\mathrm{BrO} 10 \mathrm{~F} 1 \\
- \\
- \\
- \\
-\end{array}$ & $\begin{array}{c}- \\
\text { C90700 } \\
\text { C90800 } \\
\text { C91100 } \\
\text { C91300 } \\
\end{array}$ & $\begin{array}{l}- \\
- \\
- \\
- \\
-\end{array}$ & $\begin{array}{c}- \\
\text { H5113/class } 2 \\
\text { H5113 / class 2b } \\
- \\
- \\
\end{array}$ \\
\hline Tin-zinc & $\begin{array}{c}\text { BrO8Ts4 } \\
\text { BrO10Ts2 }\end{array}$ & $\begin{array}{c}\text { C90300 } \\
\text { C90500 } \\
- \\
\end{array}$ & $\begin{array}{c}- \\
- \\
\operatorname{Rg} 10(2.1087)\end{array}$ & $\begin{array}{l}- \\
- \\
-\end{array}$ \\
\hline Tin-zinc-nickel & - & C94700 & - & - \\
\hline Tin-lead & $\begin{array}{c}- \\
- \\
- \\
- \\
\mathrm{BrO} 10 \mathrm{~S} 10 \\
- \\
- \\
- \\
- \\
- \\
\mathrm{BrO} 5 \mathrm{~S} 25 \\
- \\
\end{array}$ & $\begin{array}{l}\text { C92700 } \\
\text { C92800 } \\
\text { C93400 } \\
\text { C93600 } \\
\text { C93700 } \\
- \\
\text { C93800 } \\
\text { C93900 } \\
\text { C94000 } \\
\text { C94100 } \\
\text { C94300 } \\
\text { C } 94500 \\
\end{array}$ & $\begin{aligned} & - \\
- & \\
- & \\
- & \\
- & \\
\text { SnPbBz10 } & (2.1177) \\
\text { SnPbBz10 } & (2.1183) \\
- & \\
- & \\
\text { SnPbBz10 } & (2.1189) \\
- & \\
- & \end{aligned}$ & $\begin{array}{c}- \\
- \\
- \\
- \\
\text { H5115 } / \text { class 3.3c } \\
- \\
\text { H5115 } / \text { class } 4.4 \mathrm{c} \\
- \\
- \\
- \\
- \\
\text { H5115 } / \text { class } 5 \\
\end{array}$ \\
\hline Tin-lead-nickel & $\begin{array}{l}- \\
- \\
\end{array}$ & $\begin{array}{l}\text { C92500 } \\
\text { C92900 } \\
\end{array}$ & $\begin{array}{l}- \\
-\end{array}$ & $\begin{array}{l}- \\
-\end{array}$ \\
\hline Tin-lead-zinc & $\begin{array}{c}\text { BrO6Ts6S3 } \\
\text { BrO5Ts5S5 } \\
- \\
\text { BrO4Ts7S5 } \\
- \\
\text { BrO3Ts12S5 } \\
\text { BrO4Ts4S17 } \\
- \\
- \\
- \\
- \\
-\end{array}$ & $\begin{array}{c}- \\
\mathrm{C} 83800 \\
- \\
\mathrm{C} 83900 \\
\mathrm{C} 84200 \\
\mathrm{C} 84800 \\
- \\
\mathrm{C} 92200 \\
\mathrm{C} 92300 \\
\mathrm{C} 92600 \\
\text { C93200 } \\
\text { C93500 } \\
\end{array}$ & $\begin{aligned} &- \\
&- \\
& \operatorname{Rg} 5(2.1097) \\
&- \\
&- \\
&- \\
&- \\
&- \\
&- \\
&- \\
& \operatorname{Rg} 7(2.1091) \\
&- \\
&\end{aligned}$ & $\begin{array}{c}- \\
\text { H5111 / class 6.6c } \\
- \\
- \\
- \\
\text { H5111 } / \text { class } 1.1 \mathrm{c} \\
- \\
\mathrm{H} 5111 / \text { class } 7.7 \mathrm{c} \\
\mathrm{H} 5111 / \text { class 2.2c } \\
\mathrm{H} 5111 / \text { class 3.3c } \\
- \\
- \\
-\end{array}$ \\
\hline Tin-zinc-nickel & $\begin{array}{c}\text { BrO3Ts7S5N1 } \\
- \\
- \\
- \\
- \\
-\end{array}$ & $\begin{array}{c}- \\
\text { C } 83450 \\
\text { C94800 } \\
\text { C94900 } \\
\text { C97300 } \\
\text { C97600 }\end{array}$ & $\begin{array}{l}- \\
- \\
- \\
- \\
- \\
-\end{array}$ & $\begin{array}{l}- \\
- \\
- \\
- \\
- \\
-\end{array}$ \\
\hline
\end{tabular}

Tin bronzes in order to increase the mechanical properties and fluidity are alloyed by phosphorous which is also a deoxidizing agent.

Nickel (up to $0.25 \%$ ) has positive effect on tin-phosphorous bronzes somewhat increasing the mechanical properties and refining the grain. It also provides significant grain refinement in tin-lead bronzes that promotes more uniform distribution of lead in the castings. Nickel $(0.5-1.0 \%)$ has no observable effect on tin-zinc bronzes.
Small additions of zirconium, boron, titanium and niobium to tin bronzes improve their mechanical properties and pressure processibility in cold and hot state.

CIS countries produce bronzes, which hare no analogues in other countries (namely BrO10F1, BrO6Ts6S3, BrO4Ts4S17, and BrO3Ts7S5N1).

Main difficulties in welding and surfacing of tin bronzes. Welding and surfacing of tin bronzes are connected with specific difficulties, namely high porosity susceptibility (copper al- 
loys are the most susceptible among all), formation of solidification cracks in welds and HAZ, liquation of tin and, respectively, structure inhomogeneity, as well as penetration of tin bronze in steel during surfacing.

Porosity of welds is promoted by emission of hydrogen and water vapors from the weld pool metal during the solidification process [8, 9]. Consumables, which provide dilution of gas phase and, thus, reduction of hydrogen partial pressure in arc atmosphere (due to introduction of gas-forming constituents in a composition of electrode coating), as well as application of active agents deoxidizing the weld pool metal (electrode rods and wires, alloyed by phosphorous, silicon, manganese and aluminum) [10], are used for porosity prevention.

Great problem in welding and surfacing of cast tin bronzes is initiation of solidification cracks $[11,12]$. Intercrystalline cracks are initiated in a fusion line and can have an appearance of separate penetrations between the grains or mesh on a grain boundary. The main reason of crack formation is the liquid interlayers between the crystalline particles at the moment of tensile stress effect. Presence of the liquid interlayers depends on a content of impurities, which form fusible eutectics, in the metal. These are bismuth, sulfur and phosphorous for most of tin bronzes. Crack initiation is also related with formation of large quantity of tin-riched brittle $\delta$-phase. Susceptibility of BrO10Ts2 bronze to initiation of cracks in the welded joints increases with rise of

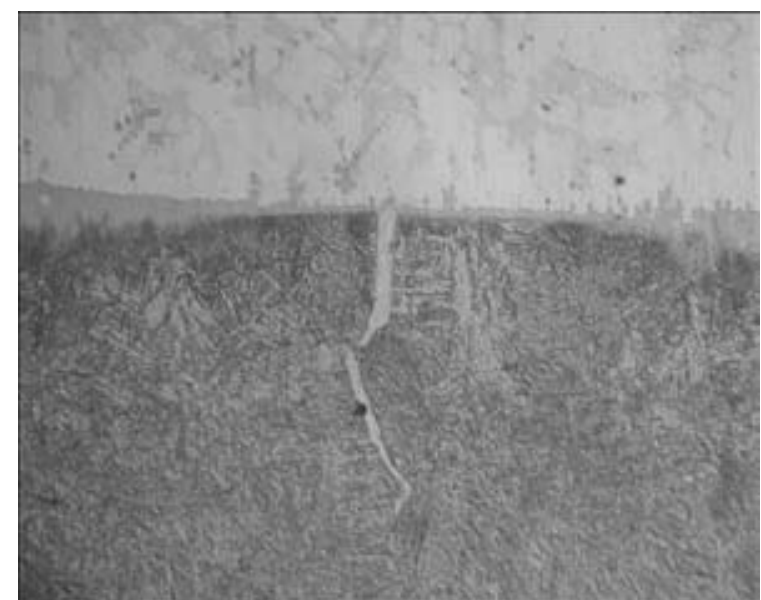

Microstructure $(\times 100)$ of fusion zone of tin bronze to steel (bronze filled crack)

tin content in the alloy and in presence of more than $0.004 \% \mathrm{~Pb}[13]$ in it. Crack is also effected by different physical-chemical properties of tin bronzes and steels and modes of surfacing on steel. Sizes of cracks are different, namely from several microns to several (and even tens) of millimeters (Figure). The measures on prevention of crack initiation in steel should be taken during surfacing of tin bronzes (perform surfacing without steel melting at minimum temperature of heating of its surface, apply intermediate surfacing by silicon bronze or yellow metal, use technological processes, at which minimum tensile stresses will be developed in steel) [14-16].

It should be noted that process of crack initiation in welding and surfacing of tin bronzes is not enough studied.

Table 2. Pressure-treat grades of tin bronzes [5]

\begin{tabular}{|c|c|c|c|c|}
\hline \multirow{2}{*}{ Alloy } & CIS & USA & Germany & Japan \\
\hline & GOST 5017-74 & $\begin{array}{c}\text { ASTM B103, B122, B139, } \\
\text { B740 }\end{array}$ & DIN 17662, 17664 & JIS H3110, H3130 \\
\hline Tin-phosphorous & $\begin{array}{c}\text { BrOF2-0.25 } \\
\text { BrOF4-0.25 } \\
- \\
\text { BrOF6.5-0.15 } \\
- \\
- \\
\text { BrOF6.5-0.4 } \\
\text { BrOF7-0.2 } \\
- \\
\text { BrOF8-0.3 } \\
-\end{array}$ & $\begin{array}{c}- \\
\text { C51100 } \\
\text { C53400 } \\
- \\
\text { C51000 } \\
\text { C53200 } \\
- \\
- \\
- \\
\text { C52100 } \\
\text { C52400 }\end{array}$ & $\begin{aligned} & - \\
\text { CuSn4 } & (2.1016) \\
- & - \\
\text { CuSn6 } & (2.1020) \\
- & \\
- & - \\
- & \\
\text { CuSn6 } & (2.1020) \\
\text { CuSn8 } & (2.1030) \\
\text { CuSn8 } & (2.1030) \\
- & \end{aligned}$ & $\begin{array}{c}- \\
\text { C5111 } \\
- \\
\text { C5191 } \\
- \\
- \\
- \\
\text { C5210 } \\
- \\
\text { C5212 } \\
- \\
\end{array}$ \\
\hline Tin-zinc & $\begin{array}{c}\text { BrOTs4-3 } \\
- \\
\end{array}$ & $\begin{array}{l}- \\
- \\
\end{array}$ & CuSn6Zn6 (2.1080) & - \\
\hline Tin-nickel & $\begin{array}{l}- \\
- \\
- \\
-\end{array}$ & $\begin{array}{l}\text { C72500 } \\
\text { C72650 } \\
\text { C72700 } \\
\text { C72900 }\end{array}$ & $\begin{aligned} \text { CuNi9Sn2 } & (2.0875) \\
- & \\
- & \\
- & \end{aligned}$ & $\begin{array}{l}- \\
- \\
- \\
-\end{array}$ \\
\hline Tin-zinc-lead & $\begin{array}{c}\text { BrOTsS4-4-2.5 } \\
- \\
\text { BrOTsS4-4-4 }\end{array}$ & $\begin{array}{c}- \\
\mathrm{C} 54400 \\
-\end{array}$ & $\begin{array}{l}- \\
- \\
-\end{array}$ & $\begin{array}{l}- \\
- \\
-\end{array}$ \\
\hline
\end{tabular}


Liquation of tin related with big temperature interval of solidification is possible in welding and surfacing of tin bronzes, due to what chemical inhomogeneity along the section and, respectively, heterogeneity of the mechanical properties take place in the metal. Welding at minimum heat input and with intervals for temperature adjustment, application of intermediate and final annealing and, as a rule, usage of consumables with reduced content of tin in comparison with welded bronze [17, 18] should be plasticized for liquation decrease.

Welding processes and consumables for surfacing and welding of tin bronzes. Many of welding processes, namely gas-shielded consumable or non-consumable electrode welding or automatic submerged-arc and manual coated-electrode arc welding have found application in industry, regardless all difficulties in welding and surfacing of tin bonzes. Plasma-arc, gas, electroslag, vibrating-electrode arc and other methods of welding and surfacing are rarely used.

Gas-shielded welding using consumable and non-consumable electrodes received the widest distribution. It differs by versatility and simplicity of shielding of weld pool metal from effect of environment. Inert gases, namely argon, helium as well as their mixtures $(\mathrm{Ar}+30 \% \mathrm{He})$ are mainly used as shielding atmosphere. Nitrogen is more rarely used.

Wires from wrouhgt bronzes which are manufactured in CIS countries and abroad (Table 2) are used depending on grade of bronze to be welded and media of part operation.

Minimizing of base metal penetration and ingress into cladding layer of iron, significantly deteriorating service properties of the deposited metal, requires application of argon-arc surfacing using consumable and non-consumable electrodes at small current densities. The most dense metal is obtained in consumable-electrode surfacing using solid wires.

Wide application of gas-shielded arc welding and surfacing of tin bronzes is prevented by low strain properties of cast tin alloys, since manufacture of welding wires from them is complicated. Necessity in small diameter wires is, in particular, high. This problem can be solved through application as filler material of fluxcored and composite wires, which allow relatively easy receiving of the metal of necessary composition and satisfactory quality.

Surfacing using split and strip electrodes [1921] should be referred to advanced methods of electric arc surfacing, allowing regulation of steel penetration in a wide range and providing high efficiency. Investigation of peculiarities of arcing and base metal penetration using such electrodes allowed determining that the minimum steel penetration at that is achieved due to intensive «erratic» arc and more favorable distribution of heat input over pool width caused by that. Rate of surfacing and current density have significant effect on the base metal penetration and iron content in the deposited layer in strip electrode surfacing. Regulation of the base metal penetration in strip electrode surfacing can be performed by $60-45^{\circ}$ angel of strip turning relatively to surfacing direction (bead axis).

Fluxes of OSTs-45, AN-20, AN-26, AN-348-A and AN-M2 grades can be used in automatic submerged-arc welding and surfacing for greater efficiency of the process. They provide the necessary level of welding-technological properties and metallurgical treatment of the weld pool. Welding wire with the same composition as in the deposited metal is preferable in surfacing and welding of tin bronzes. Production of flux-cored wires is one of the most simple and economical methods for receiving of the deposited metal of specific chemical composition in the absence of necessary welding wires. Developed are the fluxcored wires for surfacing of BrO6Ts6S3 [11] and BrO8S21 [20, 22] bronze as well as for welding of BrO10Ts2 [23].

Manual coated-electrode arc welding is widely used in industry together with automatic methods of welding and surfacing of cast tin bronzes. This process is constantly improved in order to rise the quality of deposited metal and fulfill increased service requirements.

Electrodes with different coating compositions [24] are used in arc surfacing and welding of tin bronzes. Mainly, these are coatings consisting of halogenides as well as deoxidizing, stabilizing and slag-forming materials. Overwhelming majority of coating mixtures are manufactured using sodium silicate water solution as a binding component, providing good adaptability to fabrication and application of such electrodes [17].

Drawn wires (GOST 16130-90) and cast bars of diameter not less than $6-8 \mathrm{~mm}$ are used as rods for manufacture of coated electrodes for welding and surfacing of tin bronzes. Specified standard provides for only two grades of welding wire, namely BrOF6.5-0.15 and BrOTs4-3 (Table 3). Besides, cold-roll bars are produced on GOST 10025-78 from tin-phosphor bronze of BrOF6.50.15 grade, and tin-zinc bronzes are used for drawn ones on GOST 6511-60. Bars on these standards are produced in diameter from 5 to $10 \mathrm{~mm}$ [24]. 
Table 3. Chemical composition of welding wire and rods for manual arc welding and surfacing of tin bronzes

\begin{tabular}{||c|c|c|c|c|c|c||}
\hline \hline \multirow{2}{*}{ Grade of wire and rod } & \multirow{2}{*}{$\begin{array}{c}\text { GOST on rolled-metal } \\
\text { wire } / \text { rod }\end{array}$} & \multirow{2}{*}{$\begin{array}{c}\text { GOST on chemical } \\
\text { composition }\end{array}$} & \multicolumn{4}{|c||}{ Main elements, wt.\% } \\
\cline { 4 - 6 } & & Sn & $\mathrm{P}$ & $\mathrm{Zn}$ & $\mathrm{Cu}$ \\
\hline BrOF6.5-0.15 & $16130-90 / 10025-78$ & $5017-74$ & $6.0-7.0$ & $0.10-0.25$ & - & Rest \\
\hline BrOTs4-3 & $16130-90 / 6511-60$ & $5017-74$ & $3.5-4.0$ & - & $2.7-3.3$ & \\
\hline
\end{tabular}

Cast bars provide lower quality of the deposited metal than wrought ones; therefore, they are used only in extreme case.

Table 4 shows the data on coated electrodes, which have the widest application for welding and surfacing of tin bronzes, as well as weldingup of defects of bronze casting. It can be seen that content of tin is on the level of 5.0-7.5\% (except UTP-320) and values of mechanical properties differ in several times when using of the mentioned above electrodes. For example, elongation of OZB-2M deposited metal equals $10 \%$ and that of Phosphor Bronze C Electrode makes 45-50\%; tensile strength of AS Bronz equals $260 \mathrm{MPa}$ and that of Phosphor Bronze C Electrode makes $450 \mathrm{MPa}$. In addition, given electrodes not always have good welding-technological characteristics.

Plasma method [25] received wide distribution for tin bronze surfacing. At that, wire, rods, fixed filler (stowed or in other way fixed on the surface) and powder can be used as filler material. Surfacing with solid wire filler is the most often used. The grades of these wires are given above. Specific modification of tin bronze surfacing is plasma-powder method allowing significantly ex- panding the list of alloys for mechanized surfacing. Minimum penetration of the base metal with good bead formation [25, 26] is provided in plasma surfacing. Expensive equipment and low process efficiency can be referred to method disadvantages.

Vibrating-electrode arc surfacing of copper alloys [36] finds its application in repair of small diameter cylinder parts and for surfacing of thin layers. It allows surfacing small diameter parts. The surfacing is carried out in a jet of coolant fluid or foam, having also the function of shielding media.

Electroslag surfacing of tin bronze on steel [37] can be used for one pass surfacing of large thickness layer of metal $(\geq 20 \mathrm{~mm})$. As a rule, plates or chips from bronze, which are preliminary stowed on ferrous metal, are used as filler. Advantage of electroslag surfacing is possibility of application of cast electrodes. Its disadvantage is laboriousness of preliminary operations as well as necessity of application of high currents in surfacing of large surfaces. The electroslag process is reasonable when it is necessary to surface large quantity of metal.

Other methods, namely gas surfacing and welding [38], gas-shielded pulse-arc and sub-

Table 4. Electrodes for welding (welding-up) and surfacing of tin bronzes

\begin{tabular}{|c|c|c|c|c|c|c|c|c|c|c|c|}
\hline \multirow{2}{*}{$\begin{array}{l}\text { Grade of } \\
\text { electrode }\end{array}$} & \multicolumn{7}{|c|}{ Chemical composition of deposited metal, wt.\% } & \multirow{2}{*}{$\begin{array}{l}\text { Hardness } \\
\qquad H B\end{array}$} & \multirow{2}{*}{$\delta, \%$} & \multirow{2}{*}{$\sigma_{\mathrm{t}}, \mathrm{MPa}$} & \multirow{2}{*}{ Reference } \\
\hline & Sn & $\mathrm{P}$ & $\mathrm{Mn}$ & $\mathrm{Ni}$ & $\mathrm{Fe}$ & $\mathrm{Si}$ & $\mathrm{Cu}$ & & & & \\
\hline OZB-2M & 6.0 & 0.35 & 1.0 & 0.80 & 0.5 & - & Rest & 115 & 10 & 340 & [24] \\
\hline OK 94.25 & 7.0 & 0.15 & 0.5 & - & $<0.2$ & - & 92 & 95 & $25-35$ & $330-390$ & [33] \\
\hline UTP-32 & 7.0 & - & - & - & - & - & 93 & 100 & 34 & $295-345$ & [32] \\
\hline UTP-320 & 13.0 & - & - & - & - & - & 87 & 150 & 34 & $245-295$ & [32] \\
\hline AS Bronz & 7.0 & 0.10 & 0.5 & - & - & - & Rest & 90 & 20 & 260 & [35] \\
\hline SP-33 & 5.3 & 0.09 & - & - & - & - & Same & - & 27 & 400 & [34] \\
\hline SV 082 & 8.0 & 0.10 & 0.01 & 0.05 & 0.1 & 0.05 & $\gg$ & 105 & 18 & 340 & [31] \\
\hline Capilla 48 & $6.0-8.0$ & - & - & - & - & - & 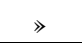 & $100-110$ & - & 280 & [30] \\
\hline $\mathrm{E}-\mathrm{CuSn}-\mathrm{C}$ & $7.0-9.0$ & $<0.30$ & \multicolumn{4}{|c|}{$\mathrm{Si}+\mathrm{Mn}+\mathrm{Fe}+\mathrm{Al}+\mathrm{Ni}+\mathrm{Zn} \leq 0.5$} & $\gg$ & - & - & - & [27] \\
\hline $\begin{array}{l}\text { Phosphor } \\
\text { Bronze C } \\
\text { Electrode }\end{array}$ & $7.0-9.0$ & $<0.35$ & - & - & 0.25 & - & 》 & $85-100$ & $45-50$ & 450 & [28] \\
\hline $\begin{array}{l}\text { Nihonweld } \\
\mathrm{N}-\mathrm{CuSn}-\mathrm{C}\end{array}$ & 7.8 & 0.11 & - & - & 0.17 & - & » & $90-100$ & 30 & 390 & [29] \\
\hline $\begin{array}{l}\text { Nihonweld } \\
\mathrm{N}-\mathrm{CuSn}-\mathrm{A}\end{array}$ & 5.15 & 0.18 & - & - & 0.52 & - & $\gg$ & $65-75$ & 24 & 424 & [29] \\
\hline
\end{tabular}


merged-arc welding [39] and spark surfacing [40] are used for welding and surfacing of tin bronze, but they have not found wide application. If these methods are used, the same consumables as considered above are applied.

\section{Conclusions}

1. The following welding processes, namely welding-up of cast defects, surfacing with the purpose of repair of worn bronze parts, welding during manufacture of welded-cast parts as well as surfacing on steel for production of bimetal parts, are successfully used for economy of expensive tin bronzes. At that, welding and surfacing metallurgical peculiarities of these alloys, i.e. increased porosity susceptibility, initiation of solidification cracks in welds and HAZ, tin liquation and, respectively, structure inhomogeneity and initiation of bronze-filled cracks in steel (during surfacing on steel) should be considered.

2. It is not always possible to produce the welding wire, which can be used for automatic welding as well as for manufacture of coated electrode rods, due to low ductility of tin bronzes.

3 . There are virtually no domestic consumables, including coated electrodes which can be used for welding, surfacing and welding-up of cast defect of bronzes with more than $8 \%$ Sn.

4. Development and mastering of production of special flux-cored wires, providing welds and deposited metal of necessary compositions and properties, is perspective for application of mechanized processes of welding and surfacing of tin bronzes in industry.

1. Ponomarenko, O.I., Shinsky, I.O., Morgun, N.N. (2004) Casting on gasified models of bronze alloys. Litejn. Proizvodstvo, 11, 30.

2. Ponomarenko, O.I., Lysenko, T.V., Stanovsky, A.L. et al. (2012) Control of casting systems and processes: Monography. Kharkov: KhPI.

3. www.non-ferrous@metalresearch.ru

4. Makarevich, O.P., Fedorov, G.E., Platonov, E.O. (2005) Production of special steel casts. Kyiv: KPI.

5. Osintsev, O.E., Fedorov, V.N. (2004) Copper and copper alloys. National and foreign grades: Refer. Book. Moscow: Mashinostroenie.

6. Smiryagin, A.P., Smiryagina, N.A., Belova, A.V (1974) Commercial non-ferrous metals and alloys: Refer. Book. Moscow: Metallurgiya.

7. Lebedev, K.P., Rajnes, L.S., Shemtov, G.S. et al (1973) Cast bronzes. Leningrad: Mashinostroenie.

8. Dzhevaga, I.I. (1961) Electric arc welding of nonferrous metals and alloys. Leningrad: Sudpromgiz.

9. Khmel, G.P., Krasnenko, E.G., Ilyushenko, V.M. et al. (1966) Surfacing of worn bronze parts of metallurgical equipment. Avtomatich. Svarka, 3, 68-71.

10. Redchits, V.V. (1991) Pore prevention in fusion welding of non-ferrous metals. Ibid., 6, 31-34.

11. Ilyushenko, V.M., Opanasenko, S.I., Fishkis, M.M. et al. (1966) Mechanized welding-up of cast defects in tin bronze. Ibid., 2, 64-66.
12. Dzhevaga, I.I., Zhuravlyov, Yu.A. (1965) Relation between structure and resistance of welds on bronze to solidification cracks. Ibid., 11, 14-19.

13. Simanenkov, L.N. (1981) Study and development of electric arc welding technology of tin bronze of Br.OTs10-2 grade: Syn. of Thesis for Cand. of Techn. Sci. Degree. Moscow.

14. Vajnerman, A.E., Osetkin, A.A. (1968) To problem of crack formation in surfacing of copper alloys on steel. Avtomatich. Svarka, 6, 23-25.

15. Timofeev, V.N., Isaev, N.I. (1965) Surfacing of copper alloys on steel surfaces. Ibid., 4, 34-37.

16. Ardentov, V.V., Vajnerman, A.E., Gajdaj, P.I. et al. Method of surfacing. USSR author's cert. 548391. Int. Cl. B23k 9/04. Fil. 05.08.1974. Publ. 28.02.1977.

17. Abramovich, V.R., Demyantsevich, V.P., Efimov, L.A. (1988) Fusion welding of copper and copperbased alloys. Leningrad: Mashinostroenie.

18. Hanke, H., Retzlaff, O., Schultz, H.-W. (1968) Schweissen von Gusszinbronze. Schweisstechnik, 2, $1-12$.

19. Timofeev, A.I., Potakhin, V.P. (1967) Automatic surfacing of Br.AMts9-2 bronze with strip electrode on coating. Svarochn. Proizvodstvo, 10, 14-16.

20. Ilyushenko, V.M., Sedov, V.E. (1969) Surfacing of tin-lead bronze on steel with split electrode. Avtomatich. Svarka, 6, 52-54.

21. Ilyushenko, V.M. (1978) Advanced methods of arc surfacing copper alloys on steel. In: Welding and surfacing of heavy non-ferrous metals. Kiev: PWI, 30-32.

22. Ilyushenko, V.M., Sedov, V.E., Opanasenko, S.I. et al. Flux-cored wire for surfacing. USSR author's certificate 202391. Int. Cl. B23k. Fil. 03.01.1966. Publ. 14.09.1967.

23. Dzhevaga, I.I., Simanenkov, L.N. Composition of welding wire. USSR author's cert. 593868. Int. Cl. B23k $35 / 30$. Fil. 18.10.1976. Publ. 25.02.1978.

24. Zaks, I.A. (1999) Electrodes for arc welding of nonferrous metals and alloys: Refer. Book. St.-Petersburg: Strojizdat.

25. Gladky, P.V., Pereplyotchikov, E.F., Ryabtsev, I.A. (2007) Plasma surfacing. Kiev: Ekotekhnologiya.

26. Ilyushenko, V.M. (1977) Welding and surfacing of heavy non-ferrous metals. Kiev: Znanie.

27. www.hzdayang.com/aws-ecusn-c.html

28. www.brazing.com/MSDS_PhosBronze_E.pdf

29. www.nihonweld.com/products.do?item id=15402

30. www.rs-nt.ru/capilla-gmbh-germany / $3 \overline{7} 6 / 2687$

31. wकw

32. (2004) UTP Schwēissmaterial GmbH. Bad Krozingen.

33. (2005) Filler materials for manual and automatic welding: ESAB Welding Handbook. 4 ed. Goeteborg.

34. (2006) Kobe steel welding consumables: Catalog. Tokyo.

35. (2005) ASKANYAK welding electrodes and wire: Catalog of products. Istanbul.

36. Patskevich, I.R., Bautina, V.A. (1962) Vibrating electrode arc surfacing of bronze on steel. Svarochn. Proizvodstvo, 11, 43-45.

37. Dudko, D.A., Shcherbina, N.Ya., Podsatsky, V.V. (1979) Electroslag surfacing of copper and its alloys on steel using boiling fluxes. Avtomatich. Svarka, 2, 34-37.

38. Gvozdem, M.S. (1963) Welding-up of defects in casts of non-ferrous metals. Litejn. Proizvodstvo, 9, 42.

39. Potapievsky, A.G., Agarkov, L.A., Osadchenko, A.E. (1967) Mechanized pulsed-arc surfacing of bronze on steel items. Sudostroenie, 8, 46-50.

40. Pushkin, I.A. (2001) Some peculiarities of recovery of worn bronze bushings by spark surfacing. In: Abstr. of Ural Welding Conf. Nizhny Tagil: NTTI, $127-129$ 